\title{
Portal Venous Pressure Variation during Hepatectomy: A Prospective Study
}

\author{
Variação da Pressão Venosa Portal durante \\ Hepatectomia: Um Estudo Prospectivo
}

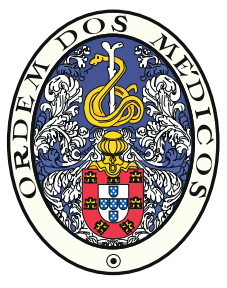

\author{
Jorge Gomes CARRAPITA $\triangle^{1,2}$, Clara ROCHA ${ }^{3,4}$, Henrique DONATO ${ }^{5}$, Alexandre COSTA ${ }^{6}$, Ana Margarida ABRANTES \\ Jorge Nunes SANTOS ${ }^{1}$, Maria Filomena BOTELHO ${ }^{7}$, José Guilherme TRALHÃO ${ }^{7}$, Jorge Maciel BARBOSA ${ }^{8,9}$ \\ Acta Med Port 2019 Jun;32(6):420-426 - https://doi.org/10.20344/amp.10892
}

\section{ABSTRACT}

Introduction: Excessive portal venous pressure in the liver remnant is an independent factor in the occurrence of posthepatectomy liver failure and small-for-size syndrome. The baseline portal pressure prior to hepatectomy was not considered previously. The aim of this study is to assess the impact of portal pressure change during hepatectomy on the patient outcome.

Material and Methods: Prospective observational study including 30 patients subjected to intraoperative measurement of portal pressure before and after hepatectomy. This variation was related to the patient outcome. Control group evaluation was assessed. Patient, disease and procedure features were considered. The optimal cut-off of portal pressure variation was determined. Linear regression or logistic regression was applied to identify predictors of the outcome.

Results: The univariate analysis showed that portal pressure increase after hepatectomy was associated with coagulation impairment in the first 30 postoperative days $(p<0.05)$, and with the occurrence of major complications $(p=0.01)$, namely hepatic failure $(p=0.041)$. The multivariate analysis showed that portal venous pressure increase $\geq 2 \mathrm{mmHg}$ is an independent factor for worse outcomes.

Discussion: As in previous studies, this study concludes that, after hepatectomy, in addition to the functional liver remnant, other factors are responsible for deterioration of liver function and patient outcome, such as the portal pressure increase and the exposure to chemotherapy prior to hepatectomy. This work may influence the definition of future indications for portal influx modulation.

Conclusion: Patient outcomes are influenced by the portal venous pressure increase: an increment $\geq 2 \mathrm{mmHg}$ after hepatectomy seems to increase the risk of major complications.

Keywords: Hepatectomy; Portal Pressure; Portal Vein

\section{RESUMO}

Introdução: O aumento da pressão venosa portal para o remanescente hepático é um fator independente para falência hepática após hepatectomia e síndrome small-for-size. Estudos anteriores não consideram o valor de pressão portal prévio à hepatectomia. O objetivo deste estudo é analisar o impacto da variação da pressão portal durante a hepatectomia na evolução clínica pós-operatória. Material e Métodos: Estudo observacional prospetivo, incluindo 30 doentes submetidos a medição intraoperatória da pressão portal antes e após hepatectomia, relacionando esta variação com a evolução clínica pós-operatória. Avaliação similar foi efetuada num grupo de controlo. Fatores relacionados com o doente, doença e procedimento foram considerados. Determinou-se o valor ideal de variação da pressão portal. Regressão linear ou logística foram aplicadas para identificar fatores preditores de evolução clínica.

Resultados: A análise univariada mostrou que um aumento de pressão portal após hepatectomia associa-se a deterioração da coagulação nos primeiros 30 dias após hepatectomia $(p<0,05)$, a complicações major $(p=0,01)$ como a falência hepática após hepatectomia $(p=0,041)$. A análise multivariada mostrou que um aumento de pressão portal $\geq 2 \mathrm{mmHg}$ é um fator independente para a evolução clínica pós-operatória desfavorável.

Discussão: Após hepatectomia, para além do remanescente hepático funcional, outros fatores são responsáveis pela deterioração da função hepática e pela morbimortalidade, como o aumento da pressão portal e a exposição prévia a quimioterapia. Este trabalho contribui para a definição futura das indicações para modulação do influxo portal.

Conclusão: Um aumento de pressão portal $\geq 2 \mathrm{mmHg}$ após hepatectomia parece agravar o risco de complicações major.

Palavras-chave: Hepatectomia; Pressão Portal; Veia Porta

\section{INTRODUCTION}

Major hepatectomy $(\mathrm{MH})$ is currently the standard treatment for benign and malignant liver disease, allowing also collecting grafts in living donor liver transplantation (LDLT).,

Over the last years, there has been an increase in survival and more acceptable morbidity and mortality rates in patients undergoing $\mathrm{MH}$ or LDLT., However, despite this progress, the mortality rate after $\mathrm{MH}$ remains worrying, with liver failure being its main cause.$^{1,5,6}$ Several studies suggest that hepatic failure after $\mathrm{MH}$ is due to reduced liver volume and hemodynamic changes, which increase oxidative stress, leading to necrosis and apoptosis. ${ }^{7-12}$ Although

\footnotetext{
1. Instituto de Ciências Biomédicas Abel Salazar. Universidade do Porto. Porto. Portugal.

2. Serviço de Cirurgia Geral. Centro Hospitalar de Vila Nova de Gaia / Espinho. Vila Nova de Gaia. Portugal.

3. ESTESC-Coimbra Health School Department Complementary Sciences. Polytechnic Institute of Coimbra. Coimbra. Portugal.

4. Institute for Systems Engineering and Computers at Coimbra (INESCC). Coimbra. Portugal.

5. Radiology Department. Centro Hospitalar e Universitário de Coimbra. Coimbra. Portugal.

6. General Surgery Department. Centro Hospitalar de Vila Nova de Gaia / Espinho. Vila Nova de Gaia. Portugal.

7. Biophysics Unit. Centre of Investigation on Environment, Genetics and Oncobiology (CIMAGO). Medical School. University of Coimbra. Coimbra. Portugal.

8. General Surgery Department. Centro Hospitalar de Vila Nova de Gaia / Espinho. Vila Nova de Gaia. Portugal.

9. Fernando Pessoa University. Porto. Portugal.

$\triangle$ Autor correspondente: Jorge Gomes Carrapita. jcarrapita@gmail.com

Recebido: 02 de junho de 2018 - Aceite: 25 de fevereiro de 2019 | Copyright @ Ordem dos Médicos 2019
} 
portal venous pressure (PVP) and flow play an important role in hepatic regeneration after hepatectomy, these rapid hemodynamic changes may lead to excessive portal venous pressure to the liver remnant, consequent sinusoidal injury, destruction of the hepatic parenchyma and hepatic dysfunction..$^{7-11} \mathrm{~A}$ similar process has been described in LDLT, which allowed identifying small-for-size syndrome (SFSS) as an important clinical entity. More recently, the concept of 'small-for-flow' based on the assumption that post-hepatectomy liver failure (PHLF) and SFSS after LDLT would have the same origin, has been proposed: the excessive portal venous flow to the liver remnant. ${ }^{7}$

Several studies have shown the importance of PVP early assessment as an independent predictor for PHLF occurrence. 1,7,8,11,13-16 However, few published studies attribute a cut-off of PVP, above which PHLF or SFSS become very likely. In addition, they do not consider other factors which influence intraoperative PVP, namely, the baseline PVP prior to hepatectomy.

The aim of this study is to assess the impact of PVP variation during hepatectomy on cytolysis, hepatic function, morbidity and mortality.

\section{MATERIAL AND METHODS}

\section{Inclusion criteria and ethical authorization}

Patients proposed for liver resection, without liver cirrhosis or anaesthetic contraindication, with a future liver remnant $(F L R)>30 \%$ and benign or malignant diagnosis were included in this study. All patients authorized the participation through informed consent, approved by the Ethics Committee of the Vila Nova de Gaia/Espinho Hospital, which also approved the study protocol.

\section{Sample characterization}

The sample included 30 patients undergoing hepatectomy, randomly selected from January 2011 to April 2016. The patient features are shown in Table 1.

The FLR, defined as the percentage of functional hepatic remnant after hepatectomy, was estimated, as previously described. ${ }^{17}$

Four patients underwent portal venous embolization, preceded by percutaneous biliary drainage of the liver remnant, as mentioned above. ${ }^{4}$ Twenty-one patients were previously or concomitantly subjected to metastasis thermoablation of the liver remnant. Mortality was defined as death within the first 90 days after hepatectomy.

\section{Control group}

Fifteen patients, who underwent right hemicolectomy, were randomly chosen in the same period. This surgical procedure induces a significant and abrupt iatrogenic PVP increase without changing the remaining liver.

\section{Measurement of portal venous pressure and surgical procedure}

The hepatectomy techniques were performed according to previous description. ${ }^{18}$ PVP was measured before and after hepatectomy, by introducing a $1.4 \mathrm{Fr}$ catheter into the portal vein, attached to the transducer that measures venous pressure during intraoperative monitoring. Central venous pressure was maintained below $5 \mathrm{mmHg}$ in both measures.

\section{Portal venous pressure variation}

The variation of PVP, defined as the difference between the values obtained after and before the procedure shows an average value $=2.33 \pm 3.7 \mathrm{mmHg}$ and median $=1 \mathrm{mmHg}$.

\section{Study endpoints}

The main endpoint of this study is to relate the variation of PVP, before and after hepatectomy, with:

a) Variation of prothrombin time (PT) and international normalized ratio (INR), total bilirubin, albumin, aspartate transaminase, alanine aminotransferase, glutamic-oxalacetic transaminase (GOT), alkaline phosphatase (AP), lactic dehydrogenase (LDH), gama-glutamyltransferase (GGT) and creatinine, measured by serum assay in the last 15 preoperative days, at 24 hours and at the $30^{\text {th }}$ day of postoperative time.

b) Clavien-Dindo morbidity score. ${ }^{19}$

c) Presence of hepatic failure according to the '50-50 criteria'5 and the International Study Group of Liver Surgery (IGSLS). ${ }^{6}$

d) Mortality defined by death within the first 90 postoperative days.

Several factors related to the patient, to the disease and to the surgical procedure that may influence the relation under analysis were considered, as showed in Table 1.

In the control group undergoing right hemicolectomy, hepatic function and cytolysis were evaluated through the variables already mentioned in the group of patients subjected to hepatectomy. Similarly, other outcome factors were considered.

\section{Statistical analysis}

The evaluation of normal distribution of quantitative variables was done according to the Shapiro-Wilk test. The comparison of continuous variables between two independent groups was done according to the independent samples t-Student test or the Mann-Whitney $U$ test. The $\chi^{2}$ test or the Fisher exact test was used for comparisons between categorical variables. For comparisons between ordinal or quantitative variables, the Rho-Spearman or the Pearson test were used.

The receiver operating characteristic (ROC) curve was applied to determine the optimal cut-off of the PVP variation, as a predictor of the outcome. Linear regression was applied to identify predictors of hepatic dysfunction and cytolysis. The significance check in the linear regression analysis was based on an F-test and the significance of single independent variables was assessed by a t-test. For the selection of variables in the multiple regression a stepwise approach was applied. To identify predictors of major complications 
Table 1 - Clinical characteristics of the patients included

\begin{tabular}{|c|c|c|c|c|c|c|c|c|c|c|}
\hline & & PVP $<2$ & & & PVP $\geq 2$ & & $p$ & & Total & \\
\hline & $\mathrm{n}$ & $\begin{array}{l}\text { Mean } \\
(\mu \pm \sigma)\end{array}$ & $\%$ & $\mathrm{n}$ & $\begin{array}{l}\text { Mean } \\
(\mu \pm \sigma)\end{array}$ & $\%$ & & $\mathrm{n}$ & $\begin{array}{l}\text { Mean } \\
(\mu \pm \sigma)\end{array}$ & $\%$ \\
\hline Age & & $59.3 \pm 12.6$ & & & $66.1 \pm 9.0$ & & 0.166 & - & $62.47 \pm 11.42$ & - \\
\hline Gender Female / Male & $10 / 6$ & & $62.5 / 37.5$ & $8 / 6$ & & $57.1 / 42.9$ & 1.00 & $18 / 12$ & - & $60 / 40$ \\
\hline Previous infection & 2 & & 12.5 & 5 & & 35.7 & 0.204 & 7 & - & 23.33 \\
\hline Diagnosis & & & & & & & 0.675 & & & \\
\hline Benign or Pre-malignant & 3 & & 18.8 & 4 & & $28 ., 6$ & & 7 & - & 23.33 \\
\hline Malignant & 13 & & 81.3 & 10 & & 71.4 & & 23 & - & 76.67 \\
\hline Hepatitis B & 1 & & 6.7 & 0 & & 0 & 1.00 & 1 & - & 3.33 \\
\hline Alcoholic consumption & 2 & & 13.3 & 0 & & 0 & 0.483 & 2 & - & 6.67 \\
\hline Smoking & 5 & & 33.3 & 1 & & 7.1 & 0.169 & 6 & - & 20 \\
\hline Diabetes mellitus & 4 & & 26.7 & 3 & & 21.4 & 1.00 & 7 & - & 23.33 \\
\hline Body mass index & & $26.6 \pm 5.1$ & & & $26.95 \pm 3.8$ & & 0.918 & - & $26.78 \pm 4.48$ & - \\
\hline Karnofsky score (\%) & $\begin{array}{c}13(100 \%) \\
2(90 \%) \\
1(80 \%)\end{array}$ & & & $\begin{array}{c}8(100 \%) \\
3(90 \%) \\
3(80 \%)\end{array}$ & & & 0.240 & - & !MED: 100 & - \\
\hline $\mathrm{ASA}^{*}$ (median) & & 2 & & & 2 & & 0.728 & - & 2 & - \\
\hline $\mathrm{FLR}^{* *}$ & & $0.69 \pm 0.18$ & & & $0.61 \pm 0.18$ & & 0.257 & - & $0.65 \pm 0.18$ & - \\
\hline \multicolumn{11}{|l|}{ Surgical procedures } \\
\hline $\begin{array}{l}\text { Multiple MTX*** / } \\
\text { segmentectomy }\end{array}$ & 2 & & & 0 & & & & 2 & - & 6.67 \\
\hline Bisegmentectomy & 3 & & & 3 & & & & 6 & - & 20 \\
\hline Trisegmentectomy & 2 & & & 1 & & & & 3 & - & 10 \\
\hline Left hepatectomy & 3 & & & 2 & & & & 5 & - & 16.67 \\
\hline $\begin{array}{l}\text { Left hepatectomy + } \\
\text { segmentectomy I }\end{array}$ & 1 & & & 1 & & & & 2 & - & 6.67 \\
\hline Right hepatectomy & 3 & & & 5 & & & & 8 & - & 26.67 \\
\hline $\begin{array}{l}\text { Right hepatectomy + } \\
\text { segmentectomy I }\end{array}$ & 1 & & & 0 & & & & 1 & - & 3,33 \\
\hline Central hepatectomy & 1 & & & 1 & & & & 2 & - & 6.67 \\
\hline ALPPS $^{ \pm}$ & 0 & & & 1 & & & & 1 & - & 3.33 \\
\hline \multicolumn{11}{|l|}{ Morbidity Mortality } \\
\hline without complications & 5 & & 31.3 & 2 & & 14.2 & & 7 & - & 23.33 \\
\hline \multicolumn{11}{|l|}{ Hepatic failure } \\
\hline ISGLS criteria & 4 & & & 0 & & & & 4 & & 13.33 \\
\hline 50-50 criteria & 2 & & & 0 & & & & 2 & & 6.67 \\
\hline \multicolumn{11}{|l|}{ Clavien Dindo score } \\
\hline - Grade I & 4 & & 25 & 2 & & 14.2 & & 6 & - & 20 \\
\hline - Grade II & 4 & & 25 & 3 & & 21.4 & & 7 & - & 23.33 \\
\hline - Grade IIIA & 1 & & 6.3 & 3 & & 21.4 & & 4 & - & 13.33 \\
\hline - Grade IIIB & 1 & & 6.3 & 1 & & 7.1 & & 2 & - & 6.67 \\
\hline - Grade IV & 1 & & 6.3 & 0 & & 0 & & 1 & - & 3.33 \\
\hline $\begin{array}{l}\text { - Grade } V \text { (mortality in the } \\
\text { first } 90 \text { days) }\end{array}$ & 0 & & 0 & 3 & & 21.4 & & 3 & - & 10 \\
\hline
\end{tabular}

*ASA: American Society of Anaesthesiologists score; !MED: median; ${ }^{* *} F L R$ : future liver remnant; ${ }^{* *}$ MTX: metastasectomies; ${ }^{ \pm}$ALLPS: associating liver partition and portal vein ligation for staged hepatectomy. 
or PHLF forward logistic regression (Wald test) was used. A significance of 0.05 was considered for all comparisons.

\section{RESULTS}

\section{Univariate analysis}

In this model, the PVP increase was associated with a coagulation impairment at 24 hours (INR24 hours: $r=0.447$, $p=0.013$ ) and on the fifth day after hepatectomy (INR5: $r=0.379, p=0.039$; PT5: $r=-0.387, p=0.038)$, compared to preoperative evaluation, as shown in Table 2 . On the $30^{\text {th }}$ postoperative day, the association between increased PVP after hepatectomy and coagulation impairment is still observed (INR30: $r=0.414, p=0.032$; PT30: $r=-0.459$, $p=0.01$ ) (Table 2.) In addition, the PVP increase is related to the serum GOT increase $(r=0.525, p=0.007)$ and serum AP increment $(r=0.701, p=0.0001)$ in the $30^{\text {th }}$ day, enzymes whose concomitant serum assay is raised in the context of hepatic dysfunction (Table 2).

The PVP increase after hepatectomy is associated with the occurrence of major complications $(p=0.01)$. In addition, the PVP variation tends to increase with the appearance of PHLF defined by the IGSLS criteria ( $p=0.041)$, as shown in Table 2. In this sample, there was no association between the PVP increase after hepatectomy and PHLF, according to the '50-50 criteria', nor with postoperative mortality (Table 2).

Considering the other factors that could interfere with the studied association, none revealed to influence the relation between the PVP variation and the outcome analysed. However, if we observe the influence of each factor on the outcome variables, we find that the decrease in FLR interferes with the coagulation impairment (INR24h: $r=-0.492, p=0.006$; INR5: $r=-0.474, p=0.008$ ). Besides that, chemotherapy prior to hepatectomy was associated with coagulation impairment in the fifth postoperative day $(r=0.362, p=0.049)$.

\section{Multivariate analysis}

In the multiple linear regression model (Table 3), when we analysed the cumulative effect of PVP variation during hepatectomy and FLR, we found that they influence the coagulation at 24 hours, accounting for $32.5 \%$ of the INR variance $\left(r^{2}=0.325, p<0.01\right)$. The PVP increase after hepatectomy causes an INR increment at 24 postoperative hours ( $\beta=0.385, p<0.05)$, while, as expected, the FLR increase has an opposite effect on the INR ( $(=-0.355, p<0.05)$.

In addition, the results show that PVP variation and exposure to chemotherapy (CHEMO) prior to hepatectomy lead to a cumulative coagulation impairment, accounting for $35.8 \%$ of the INR variance on the 30th postoperative day $\left(r^{2}=0.423, p<0.01\right)$, through a positive effect of both (PVP: $\beta=0.538, p<0.01)($ CHEMO: $\beta=0.423, p<0.05)$ (Table 3). The results also show that the PVP and FLR variation influence the degree of hepatic cytolysis after hepatectomy: it accounts for $61.1 \%$ of the AP serum assay variance on the $30^{\text {th }}$ postoperative day $\left(r^{2}=0.611, p<0.001\right)$. While the former causes an AP serum increment $(B=0.674$,
Table 2 - Correlation between the PVP variation and the variation of the variables studied before and after hepatectomy

\begin{tabular}{lcc}
\hline & $\begin{array}{c}r \\
\text { (correlation) }\end{array}$ & $\begin{array}{c}p \\
\text { (significance) }\end{array}$ \\
\hline INR24 hours & 0.447 & 0.013 \\
PT24 hours & -0.397 & 0.033 \\
Ldh24 hours & 0.542 & 0.005 \\
INR5 & 0.379 & 0.039 \\
PT5 & -0.387 & 0.038 \\
inr30 & 0.414 & 0.032 \\
PT30 & -0.459 & 0.01 \\
AP 30 & 0.701 & 0.0001 \\
gOt30 & 0.525 & 0.007 \\
Clavien-Dindo & & 0.01 \\
PHLF (ISGLS criteria) & & 0.041 \\
PHLF (50-50 criteria) & & n.s. \\
Mortality & & n.s.
\end{tabular}

INR24 hours/5/30: variation of international normalized ratio between preoperative time and 24 hours, fifth and $30^{\text {th }}$ postoperative days; PT 24 hours/5/30: prothrombin time variation between preoperative time and 24 postoperative hours; LDH 24 hours: lactic dehydrogenase variation between preoperative time and 24 postoperative hours; AP 30: alkaline phosphatase variation between preoperative time and 24 postoperative hours; GOT 30: glutamic-oxalacetic transaminase variation between preoperative time and 30th postoperative day; Clavien - Dindo: postoperative morbidity score; PHLF: posthepatectomy liver failure according to ISGLS criteria or ' $50-50$ ' criteria. Mortality: defined as death in the first postoperative 90 days.

$p<0.001)$, the second has an opposite effect $(B=-0.305$, $p<0.05$ ). This evidence is corroborated by the similar effect of the PVP increase on serum GGT on the 30th postoperative day $(B=0.606 ; p<0.01)$, being responsible for $36.8 \%$ of the serum GGT variance $\left(r^{2}=0.368 ; p<0.01\right)$ (Table 3 ).

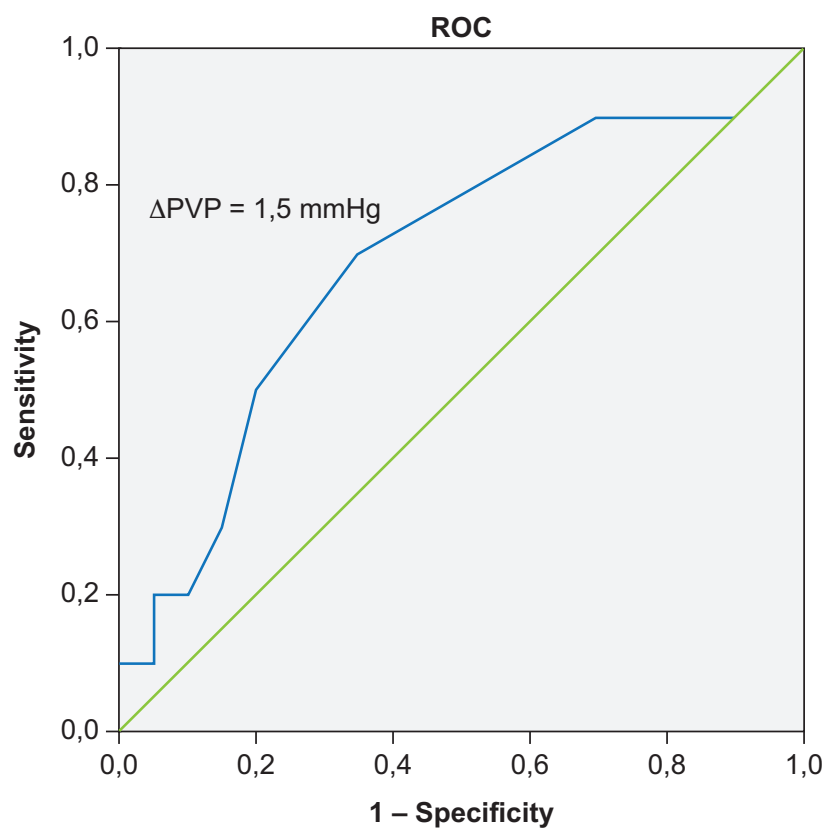

Figure $1-$ ROC (AUC $=0.69)$ used to define the PVP increment cut-off for the occurrence of major complications 
Table 3 - Multivariate analysis

\begin{tabular}{|c|c|c|c|c|}
\hline MLRM! & B & EPB & $\beta$ & $\mathbf{r}^{2}$ \\
\hline \multicolumn{5}{|l|}{ DINR 24 hours/preoperative } \\
\hline$\nabla P P^{++}$ & 0.056 & 0.023 & $0.385^{*}$ & $0.325^{\text {** }}$ \\
\hline $\mathrm{FLR}^{+++}$ & -0.672 & 0.304 & $-0.355^{\star}$ & \\
\hline \multicolumn{5}{|l|}{ DINR 30/ preoperative } \\
\hline$\nabla P V P^{++}$ & 0.032 & 0.01 & $0.538^{\star *}$ & $0.358^{* *}$ \\
\hline Chemotherapy prior hepatectomy & 0.025 & 0.01 & $0.423^{*}$ & \\
\hline \multicolumn{5}{|l|}{$\nabla \mathrm{AP}^{++++} 30 /$ preoperative } \\
\hline$\nabla \mathrm{PVP}^{++}$ & 19.4 & 3.97 & $0.674^{* * *}$ & $0.611^{\star * \star}$ \\
\hline $\mathrm{FLR}^{+++}$ & -97.8 & 44.1 & $-0.305^{\star}$ & \\
\hline SLRM! & B & EPB & $\beta$ & $\mathbf{r}^{2}$ \\
\hline \multicolumn{5}{|l|}{$\nabla G^{+++++} 30 /$ preoperative } \\
\hline$\nabla \mathrm{PVP}^{++}$ & 43.3 & 11.8 & $0.606^{\star *}$ & $0.368^{* *}$ \\
\hline \multicolumn{5}{|l|}{ DINR5 } \\
\hline$P V P \geq 2 / P V P<2$ & 0.15 & 0.058 & $0.45^{*}$ & $0.203^{*}$ \\
\hline LRM"! & $\mathbf{R R}$ & IC $95 \%$ & $p$ & \\
\hline \multicolumn{5}{|l|}{ Clavien-Dindo } \\
\hline Previous infection & 3.1 & $0.369-26.1$ & 0.297 & \\
\hline$P \vee P \geq 2$ & 0.124 & $0.018-0.837$ & 0.032 & \\
\hline
\end{tabular}

$\nabla$ : variation. 'MLRM: Multiple linear regression model. 'SLRM: Simple linear regression model. "'LRM: Logistic regression model. +RR: Risk ratio. ${ }^{++}$PVP: Portal venous pressure. ${ }^{++}$FLR: Future liver remnant. ${ }^{+++}$AP: alkaline phosphatase.${ }^{++++}$GGT: gamma-glutamyltransferase. PVP $\geq 2 / P V P<2$ : Stratified PVP $<2 \mathrm{~mm} \mathrm{Hg}$ or $\geq 2 \mathrm{~mm} \mathrm{Hg} .{ }^{*} p<0.05 ;{ }^{* *} p<0.01 ;{ }^{* *} p<0.001$

\section{PVP variation cut-off during hepatectomy}

The ROC curve shows that a PVP increment after hepatectomy greater than $1.5 \mathrm{mmHg}$ is the optimal cut-off for the occurrence of major complications, with a sensitivity of $70 \%$ and specificity of 65\% (AUC = 0.69), as shown in Fig. 1.

By reclassifying the PVP variation as a binary variable ( $P V P<2 \mathrm{mmHg}$ and PVP $\geq 2 \mathrm{mmHg}$ ), in a univariate analysis, we confirm that patients undergoing hepatectomy and exhibiting a PVP increment $\geq 2 \mathrm{mmHg}$ express a greater deterioration of the coagulation at 24 postoperative hours (INR24 hours: $p=0.006$ ), which remains at the following time points (INR5: $p<0.029)($ INR30: $p=0.033)$, compared to patients with a PVP increase $<2 \mathrm{mmHg}$. This greater coagulation impairment in the first 30 days after hepatectomy is confirmed by the serum LDH increase at 24 postoperative hours $(p=0.026)$ and by the serum AP increment on the $30^{\text {th }}$ postoperative day $(p=0.001)$, in the group of patients exhibiting PVP $\geq 2 \mathrm{mmHg}$, as shown in Table 4 .

Table 4 - Univariate analysis of portal venous pressure as binary variable: $P V P<2 \mathrm{~mm} \mathrm{Hg}$ versus PVP $\geq 2 \mathrm{~mm} \mathrm{Hg}$

\begin{tabular}{lccc}
\hline & PVP $<2 \mathbf{~ m m ~ H g}$ & PVP $\geq 2 \mathbf{~ m m ~ H g}$ & $p$ \\
\hline INR24 hours & $0.41 \pm 0.25$ & $0.62 \pm 0.45$ & 0.006 \\
INR 5 & $0.1 \pm 0.11$ & $0.2 \pm 0.24$ & 0.029 \\
INR30 & $0.04 \pm 0.08$ & $0.12 \pm 0.1$ & 0.033 \\
LDH 24 hours & $68.4 \pm 90.7$ & $993 \pm 1731$ & 0.026 \\
AP 30 & $36.8 \pm 46.3$ & $102.7 \pm 73.6$ & 0.001 \\
\hline
\end{tabular}

INR24 hours/5/30: variation of international normalized ratio between preoperative time and 24 hours, fifth and $30^{\text {th }}$ postoperative days; LDH 24 hours: lactic dehydrogenase variation between preoperative time and 24 postoperative hours; AP 30: alkaline phosphatase variation between preoperative time and $30^{\text {th }}$ postoperative day.
In the stepwise linear regression analysis, it is shown that PVP increment $\geq 2 \mathrm{mmHg}$ is an independent factor for the worse coagulation impairment after hepatectomy, accounting for $20.3 \%$ of the INR increase on the fifth postoperative day $\left(r^{2}=0.203 ; p<0.05\right)$, as shown in Table 3 . Moreover, it is shown, in a forward logistic regression model, that a PVP increment $\geq 2 \mathrm{mmHg}$ after hepatectomy is also an independent factor for the occurrence of major complications, being clear that the patients with this condition have an $8.1 \%$ increased risk (OR $=0.124, p=0.032)$ of major complications compared to patients with PVP $<2 \mathrm{mmHg}$ (Table 3).

\section{Control group}

Patients in the control group, undergoing right hemicolectomy without hepatic resection, exhibit a coagulation impairment in the first 24 hours after surgery, expressed by the INR increase $(p=0.014)$ and by PT decrease $(p=0.008)$, compared to the preoperative assays. On the fifth and $30^{\text {th }}$ postoperative days, coagulation improved, compared to the preoperative control. Furthermore, there is a serum albumin decrease in the first 24 hours, compared to the preoperative period $(p=0.001)$, which does not persist in the following time points.

If we analyse the cytolysis and the excretory and synthesis hepatic functions, we do not detect significant variation in the first 30 postoperative days.

\section{DISCUSSION}

This model demonstrates that PVP increase is a predictive factor of coagulation impairment, at 24 hours after hepatectomy, when analysed concomitantly with the future liver remnant. In addition, this coagulation impairment is maintained on the $30^{\text {th }}$ postoperative day, if we consider the 
joint influence of exposure to chemotherapy prior to hepatectomy. This hepatic functional decrease is corroborated by an increase in serum GGT and AP on the $30^{\text {th }}$ postoperative day, which are indicators of liver injury that are widely used in clinical practice. This association between increased PVP and hepatic functional deterioration also occurs in the control group in the first 24 hours, in which an increase in PVP is induced without associated hepatic resection, indicating that the increase in PVP has deleterious effects on the liver, in accordance with previous studies. ${ }^{1,7,8,11,13-16}$ However, unlike patients undergoing hepatectomy, there is a coagulation recovery at the following evaluation time points and a concomitant absence of additional hepatic dysfunction, indicating that deterioration of hepatic function after hepatectomy is multifactorial.

As in previous studies, ${ }^{1,3,20}$ this work supports the hypothesis that the cause of liver function deterioration is not only the functional percentage of the remaining liver, but also other factors such as the PVP increase after hepatectomy and the exposure to chemotherapy prior to hepatectomy. Even though portal venous flow plays a significant role in liver regeneration, these quick hemodynamic changes can lead to excessive portal venous flow to the residual liver, which generates portal hyperperfusion. Several factors are implicated in the pathogenesis of this phenomenon, namely the increased production of reactive oxygen species and cytokines induced by hemodynamic changes which, by itself, leads to hepatocyte necrosis and apoptosis. Besides this, it is also reported that portal hyperperfusion destroys the hepatic sinusoidal network, by excessive shear forces on its walls, leading to periportal bleeding and endothelial destruction. Another explanation is based on the abrupt and excessive regenerative stimulus induced by portal hyperperfusion, which, particularly in the early hours, leads to excessive hepatocyte proliferation not supported by an organized sinusoidal network to ensure adequate blood supply to the hepatocytes, thus compromising liver function. ${ }^{11}$

Previous investigations ${ }^{1,21}$ based on the measurement of PVP after hepatectomy or LDLT, attribute a post-hepatectomy PVP cut-off of 20 or $21 \mathrm{mmHg}$, from which the risk of hepatic failure is higher. However, they do not consider the baseline PVP before hepatectomy. Currently, the underlying mechanisms to PVP variation after hepatectomy are poorly understood in humans. In addition, the PVP variability in the human model is unknown, such as all the factors that may influence it. Thus, the novelty of this study is the prediction of the occurrence of severe hepatic dysfunction after hepatectomy considering PVP variation before and after hepatectomy and not only a single measurement after hepatectomy. This problem becomes more important if, in the future, we could define which patients benefit from the intraoperative portal influx modulation procedure, which may be an effective strategy for preventing hepatic failure after hepatectomy. ${ }^{1,22}$ However, this model has some limitations. One of them is the small sample size. Another problem is the selection of variables to perform the regression analysis, when a high number of independent variables that are candidates for the selection is present. To deal with this, a stepwise selection was performed. Eveb though stepwise regression analysis is popular, some authors consider that these methods are poor, because they may not identify sets of variables that fit well, even when such sets exist ${ }^{23}$ and a parameter estimates are likely to be too far away from zero. ${ }^{24}$ Nonetheless, despite these limitations, this model shows that a PVP increment $\geq 2 \mathrm{mmHg}$ after hepatectomy worsens hepatic coagulation function during the first five postoperative days and carries an increased risk of major complications. In our opinion, this not only demonstrates the need to evaluate PVP variation intraoperatively, but may also influence other studies, contributing to the future definition of indications for portal influx modulation.

\section{CONCLUSION}

PVP increase during hepatectomy influences the deterioration of liver function in the postoperative period. A PVP increase $\geq 2 \mathrm{mmHg}$ after hepatectomy, compared to baseline, increases the risk of major complications.

\section{PROTECTION OF HUMANS AND ANIMALS}

The authors declare that the procedures were followed according to the regulations established by the Clinical Research and Ethics Committee and to the Helsinki Declaration of the World Medical Association.

\section{DATA CONFIDENTIALITY}

The authors declare having followed the protocols in use at their working center regarding patients' data publication.

\section{CONFLICTS OF INTEREST}

All authors report no conflict of interest.

\section{FUNDING SOURCES}

This research received no specific grant from any funding agency in the public, commercial, or not-for-profit sectors.

\section{REFERENCES}

1. Allard MA, Adam R, Bucur PO, Termos S, Cunha AS, Bismuth $H$, et al. Posthepatectomy portal vein pressure predicts liver failure and mortality after major liver resection on noncirrhotic liver. Ann Surg. 2013;258:822-9.

2. Belghiti J, Kianmanesh R. Surgical treatment of hepatocellular carcinoma. HPB. 2005;7:42-9.

3. Asencio JM, García Sabrido JL, Olmedilla L. How to expand the safe limits in hepatic resections? J Hepatobiliary Pancreat Sci. 2014;21:399-404.
4. Farges $\mathrm{O}$, Belghiti J, Kianmanesh $\mathrm{R}$, Regimbeau JM, Santoro $\mathrm{R}$, Vilgrain V, et al. Portal vein embolization before right hepatectomy: prospective clinical trial. Ann Surg. 2003;237:208-17.

5. Balzan S, Belghiti J, Farges O, Ogata S, Sauvanet A, Delefosse D, et al. The "50-50 criteria" on postoperative day 5: an accurate predictor of liver failure and death after hepatectomy. Ann Surg. 2005;242:824-9.

6. Rahbari NN, Garden OJ, Padbury R, Brooke-Smith M, Crawford M, Adam R, et al. Posthepatectomy liver failure: a definition and grading by the International Study Group of Liver Surgery (ISGLS). Surgery. 
2011;149:713-24.

7. Asencio JM, Vaquero J, Olmedilla L, García Sabrido JL. 'Smallfor-flow' syndrome: shifting the 'size' paradigm. Med Hypotheses. 2013;80:573-7.

8. Chen X, Zhai J, Cai X, Zhang Y, Wei L, Shi L, et al. Severity of portal hypertension and prediction of postoperative liver failure after liver resection in patients with Child-Pugh grade $\mathrm{A}$ cirrhosis. $\mathrm{Br} \mathrm{J}$ Surg. 2012;99:1701-10.

9. Vasavada BB, Chen CL, Zakaria M. Portal flow is the main predictor of early graft dysfunction regardless of the GRWR status in living donor liver transplantation - a retrospective analysis of 134 patients. Int J Surg. 2014;12:177-80.

10. lida T, Yagi S, Taniguchi K, Hori T, Uemoto S. Improvement of morphological changes after $70 \%$ hepatectomy with portocaval shunt: preclinical study in porcine model. J Surg Res. 2007;143:238-46.

11. Fondevila $C$, Hessheimer AJ, Taurá $P$, Sánchez $O$, Calatayud $D$, de Riva N, et al. Portal hyperperfusion: mechanism of injury and stimulus for regeneration in porcine small-for-size transplantation. Liver Transpl. 2010;16:364-74.

12. Ninomiya M, Shirabe K, Terashi T, ljichi H, Yonemura $Y$, Harada N, et al Deceleration of regenerative response improves the outcome of rat with massive hepatectomy. Am J Transplant. 2010;10:1580-7.

13. Berzigotti A, Reig M, Abraldes JG, Bosch J, Bruix J. Portal hypertension and the outcome of surgery for hepatocellular carcinoma in compensated cirrhosis: a systematic review and meta-analysis. Hepatology. 2015;61:526-36.

14. Hidaka M, Takatsuki M, Soyama A, Tanaka T, Muraoka I, Hara T, et al. Intraoperative portal venous pressure and long-term outcome after curative resection for hepatocellular carcinoma. $\mathrm{Br} J$ Surg 2012;99:1284-9.
15. Tralhão JG, Abrantes AM, Hoti E, Oliveiros B, Cardoso D, Faitot F, et al. Hepatectomy and liver regeneration: from experimental research to clinical application. ANZ J Surg. 2014;84:665-71.

16. Leng J, Xing H, Tan J, Chen K, Dong J. The safe minimally ischemic liver remnant for small-for-size syndrome in porcine hepatectomy. Transplant Proc. 2013;45:2419-24.

17. Lodewick TM, Arnoldussen CW, Lahaye MJ, van Mierlo KM, Neumann UP, Beets-Tan RG, et al. Fast and accurate liver volumetry prior to hepatectomy. HPB. 2016;18:764-72.

18. Bismuth $H$, Houssin D, Castaing D. Major and minor segmentectomies "réglées" in liver surgery. World J Surg. 1982;6:10-24.

19. Dindo D, Demartines N, Clavien PA. Classification of surgical complications. Ann Surg. 2004;240:205-13.

20. Eshkenazy R, Dreznik Y, Lahat E, Zakai BB, Zendel A, Ariche A. Smal for size liver remnant following resection: prevention and management. Hepatobiliary Surg Nutr. 2014;3:303-12.

21. Ito T, Kiuchi T, Yamamoto H, Oike F, Ogura Y, Fujimoto Y, et al. Changes in portal venous pressure in the early phase after living donor liver transplantation: pathogenesis and clinical implications. Transplantation. 2003;75:1313-7.

22. Carrapita J, Abrantes AM, Campelos S, Gonçalves AC, Cardoso D, Sarmento-Ribeiro $A B$, et al. Impact of splenic artery ligation after major hepatectomy on liver function, regeneration and viability. Sci Rep. 2016;6:34731.

23. Miller A. Subset selection in regression. 2nd ed. London: Chapman \& Hall; 2002.

24. Harrell F. Regression modeling strategies with applications to linear models, logistic and ordinal regression, and survival analysis. 2nd ed. New York: Springer International Publishing; 2001. 